\title{
THE IMPROVEMENT, UTILIZATION AND PRODUCTION OF LOW ALTITUDE TUSSOCK COUNTRY IN OTAGO
}

T. E. LUDECKE

\author{
Scientist, Department of Agriculture, Ruakura \\ Agricultural Research Centre \\ B. P.J. Molloy \\ Scientist, Department of Agriculture, Lincoln
}

IN THIS PAPER it is planned to review research work in Central Otago and the work carried out at Tara Hills High Country Research Station, Omarama, prior to 1966, into the improvement of low altitude tussock country, the utilization of this improved country and the increases in production which can occur. Discussion will mainly be concerned with the improvement of tussock country in areas where the rainfall is greater than 20 in. per annum and where clovers can be introduced by oversowing. Lucerne is the legume suited to areas where the rainfall is less than 20 in.

The aim of tussock country improvement is two-fold, first, to improve pastoral production both by increasing stock performances (i.e., increasing wool weights and lambing percentages, decreasing death rates and raising fat lambs) and by increasing sheep and cattle numbers; secondly, to improve the lower country, so that the grazing pressure can be eased and the necessity for burning eliminated in tall tussock grasslands where soil and water conservation is vital for irrigation and hydro-electric schemes. The improvement of low altitude tussock country has been made possible by the control of rabbits and the development of an efficient aerial topdressing industry.

\section{Improvement}

The key to improving the native tussock grasslands of the South Island is to obtain good legume growth. In these areas, the main nutrient deficiencies which limit the 
growth of legumes are sulphur, phosphorus and molybdenum (Walker et al., 1955; Lobb and Bennetts, 1958; Ludecke, 1960; and McLeod, 1961). Sulphur deficiencies are very widespread probably because of low atmospheric returns.

The soil sequences in Central Otago have been described by Leamy (1966). In soil fertility investigations in Central Otago extensive use has been made of soil sequences.

The manner in which a rational fertilizer programme was formulated for the tussock grassland regions of Central Otago has been described elsewhere (Ludecke, 1960, 1962, 1962a, and 1966a). With the exception of a small area of very dry soils, all soils in Central Otago are acutely sulphur deficient and vary in their phosphate and molybdenum requirements; as the rainfall increases and the soils become more leached, the responses to phosphate and molybdenum in the presence of sulphur increase. Farm advisory officers can now give all farmers sound topdressing advice. The recognition of widespread sulphur deficiencies in Central Otago and the formulation of a rational fertilizer programme has been of tremendous significance to the economy of Otago.

Ludecke (1965) showed that in Central Otago gypsum is a superior form of sulphur to elemental sulphur and also that fineness of grinding of elemental sulphur was very important. The Dominion Fertilizer Co., Dunedin, has made excellent use of these findings and is now adding the finest elemental sulphur to superphosphate that is permissible so that the fertilizer can be applied aerially.

On the more leached soils, outstanding responses have been obtained to inoculation of clover seed with a good viable strain of rhizobia bacteria. It has been shown conclusively that oversowing with inoculated seed should be carried out in July and August. Marked depressions have been obtained to both lime pelleted inoculated white clover seed and also gafsa phosphate-dolomite pelleted inoculated clover seed. It has been shown also that inoculated seed can be mixed for five minutes with sulphurized superphosphate without any adverse effects to the inoculant (Cullen and Ludecke, 1966; Ludecke and Douglas, in preparation).

Sweet brier threatened to become a serious weed problem in Central Otago, like other tussock grassland regions 
of the South Island, particularly in the period immediately after the rabbit pest had been brought under control. It was the spread of sweet brier which was alarming. It was observed that sweet brier colonized areas where there was little or no competition from the sward, and where grazing pressures were light. In a large glasshouse experiment conducted from October to March, Molloy (1964, 1966) showed conclusively that sweet brier was intolerant of competition from pasture plants. In this experiment sweet brier was grown alone, and with sweet vernal and browntop. The grasses were either left uncut or cut frequently. The sweet brier was uncut. A soil of low fertility was used and the fertility was varied by

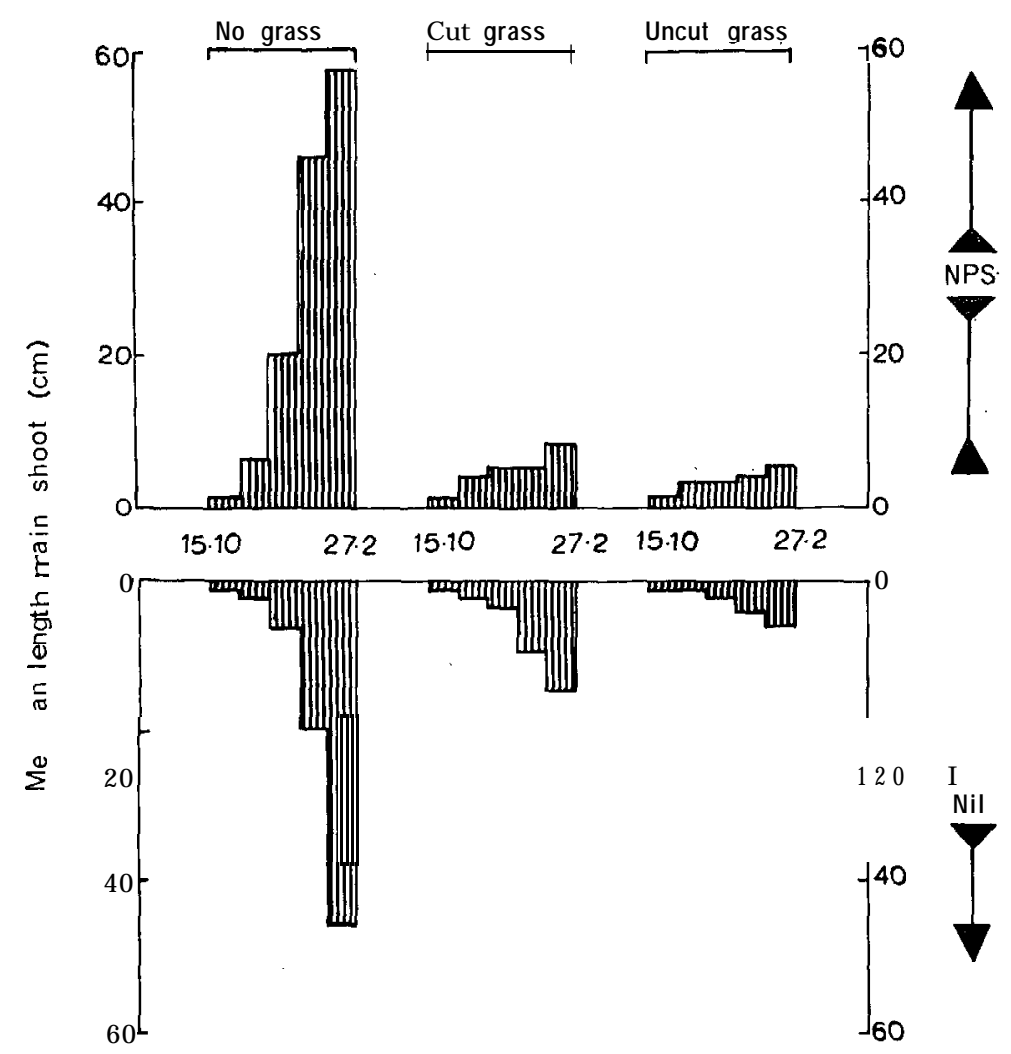

FIG. 1: Results of experiment measuring sweet brier growth. 
adding different combinations of nitrogen, phosphate and sulphur fertilizers. The results are shown in diagrammatic form in Fig. 1. The average length of the main stem of sweet brier grown alone, without added fertilizers, was $58 \mathrm{~cm}$ at the end of the trial, whereas it was only $16 \mathrm{~cm}$ in the cut grass, and $9 \mathrm{~cm}$ in the uncut grass. These marked competition effects are independent of fertility.

This glasshouse experiment has been followed by a large current trial by Molloy and Ludecke. This experiment is at the property of J. R. Scurr, Spots Creek Station, Cardrona Valley, Wanaka, an area where the spread of sweet brier was particularly alarming. A 300-acre block of tussock country was oversown and topdressed in August, 1963, with the following seed and fertilizer mixture per acre : $1 \frac{1}{2}$ cwt sulphurized superphosphate (400 lb mixture) ; $2 \mathrm{lb}$ white clover; $2 \mathrm{lb}$ Montgomery red clover; $1 \mathrm{lb}$ alsike clover; 2 lb cocksfoot.

The area was oversown and topdressed again in August, 1965, with : 1 1/2 cwt sulphurized molybdic superphosphate (400 lb mixture) ; $1 \mathrm{lb}$ white clover; $1 \mathrm{lb}$ Montgomery red clover; $1 \mathrm{lb}$ cocksfoot.

This is steep fescue tussock country which was severely depleted by rabbits in the past, but the vegetation had recovered well before topdressing was commenced, particularly on the darker aspects. The altitude of the block is $1,200 \mathrm{ft}$, the rainfall is approximately $24 \mathrm{in}$. per annum, and the soils are dry hygrous yellow-grey earths. The block consists of three aspects, sunny, dark and intermediate. The results of this oversowing and topdressing have been outstanding. The resident brier greater than $1 \mathrm{ft}$ high present on the different aspects in January, 1965, is shown in Table 1.

The sweet brier is particularly dense on the intermediate faces which are adjacent to the Cardrona riverbed, which is the sweet brier seed source. The tallest brier is also on

TABLE I: NUMBER AND HEIGHT OF SWEET BRIER PLANTS GREATER THAN $1 \mathrm{FT} / \mathrm{SQ}$. CHAIN PLOT IN 1965

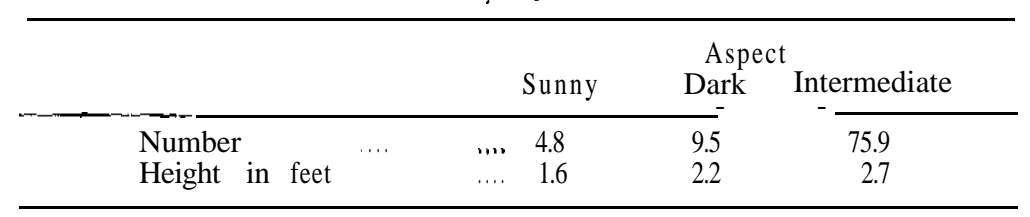


the intermediate aspects. There is little sweet brier on the sunny faces, probably owing to the lack of soil moisture, and on the well-clothed dark faces owing to competition. The number of sweet brier plants less than $1 \mathrm{ft}$ high in the years from 1964 until 1966 are shown in Tabie 2.

It can be seen that there has been a marked decline in the numbers, particularly on the intermediate faces. Thus this grazed improved sward is markedly suppressing the spread of seedling plants. Observations also suggest that resident brier is also markedly weakened by this competition. Resident sweet brier bushes which are accessible and are causing stock movement problems can be eliminated very successfully with the chemical picloram.

In the large-scale trial in the Cardrona Valley which has been described above, the changes in species composition following oversowing have also been studied by the point analysis method of botanical analysis. Some of the results are summarized in Table 3.

TABLE 2: NUMBER OF SWEET BRIER PLANTS LESS THAN 1 FT/10 QUADRATS

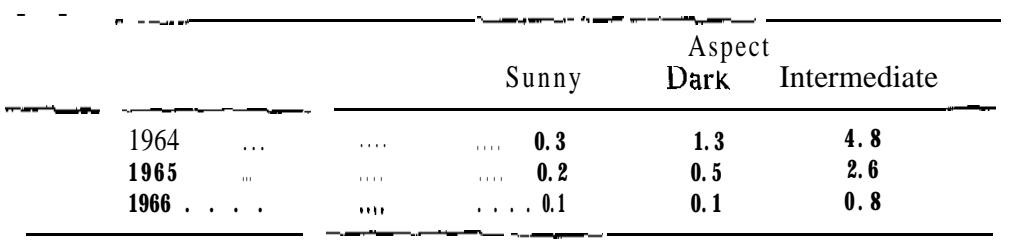

TABLE 3: COVER HITS/100 POINTS

\begin{tabular}{|c|c|c|c|c|}
\hline & Date & Sunny & $\begin{array}{l}\text { Aspect } \\
\text { Dark }\end{array}$ & Intermediate \\
\hline \multirow[t]{2}{*}{ Bare ground } & 1964 & 46.9 & 20.2 & 30.3 \\
\hline & 1966 & 30.7 & 7.3 & 10.4 \\
\hline \multirow[t]{2}{*}{ White clover } & ..." 1964 & 0.2 & 5.8 & 12.2 \\
\hline & 1966 & 7.7 & 11.1 & 23.2 \\
\hline \multirow[t]{2}{*}{ Red clover . . . . } & 1964 & 0.1 & 4.0 & 2.9 \\
\hline & 1966 & 3.4 & 31.2 & 23.4 \\
\hline \multirow[t]{2}{*}{ Cocksfoot . . . . } & .1964 & 0 & 0 & 0 \\
\hline & 1966 & 0.1 & 0.8 & 1.3 \\
\hline \multirow{2}{*}{ Blue wheatgrass } & $\ldots 1964$ & 0.6 & 6.0 & 4.0 \\
\hline & 1966 & 0.6 & 4.3 & 2.9 \\
\hline \multirow{2}{*}{ Fescue tussock } & .... 1964 & 14.8 & 22.4 & 17.3 \\
\hline & 1966 & 12.9 & 18.6 & 9.2 \\
\hline
\end{tabular}


TABLE 4: PERCENTAGE GROUND COVERED

Fertilizer Treatment: $1 \mathrm{lb}$ per Acre

\begin{tabular}{|c|c|c|}
\hline & $\begin{array}{l}56 \text { lb } \mathrm{P} \\
\text { No } \quad \mathrm{S}\end{array}$ & $\begin{array}{l}561 \mathrm{~b} \mathrm{P} \\
50 \mathrm{lb} \mathrm{S}\end{array}$ \\
\hline Clovers & $\ldots \quad 3$ & 48 \\
\hline Cocksfoot & $\ldots 0$ & 12 \\
\hline Fescue tussock .... & $\ldots 13.5$ & 23 \\
\hline Blue tussock & $\ldots 14$ & 16 \\
\hline Native and introduced grasses & $\ldots 10$ & 14 \\
\hline Bare ground .... & $\ldots \quad 37.5$ & 4 \\
\hline
\end{tabular}

There has been a marked decline in bare ground; this has particular significance to soil and water conservation. White clover and red clover have increased markedly, particularly on the intermediate faces where the resident sweet brier was the most dense, and the depression in numbers of sweet brier plants less than $1 \mathrm{ft}$ high was very marked. Cocksfoot is increasing on the dark and intermediate aspects as the nitrogen levels are raised. The amounts of blue wheatgrass (Agropyron scabrum) and fescue tussock (Festuca novae-zealandiae) have declined. The oversowing and topdressing has been particularly successful epecially on the dark and intermediate aspects. The importance of building up the nitrogen levels in fescue tussock soils so that grasses become an important component of the sward is shown clearly in Table 4.

This shows the percentage ground covered by different species in two treatments of rates of phosphate by rates of sulphur trial, at Mt. Burke Station, Wanaka. The trial was laid down in August, 1960, and the trial area was oversown with $2 \mathrm{lb}$ white clover, $2 \mathrm{lb}$ Montgomery red clover, $2 \mathrm{lb}$ alsike clover and $3 \mathrm{lb}$ cocksfoot per acre. The trial area has received no further seed since, but the fertilizers were applied again in 1964 . The point analysis measurements were taken in the summer of 1964. In the plots which received phosphate alone there was negligible clover growth owing to a marked sulphur deficiency, hence no build-up in fertility, and consequently no cocksfoot growth. In the plots which received sulphur and phosphate the amount of clover increased from 3\% to $48 \%$. This increase in the amount of clover was accompanied by an increase in the amount of cocksfoot from 0 to $12 \%$. Bare ground decreased from $37.5 \%$ to $4 \%$. This increase 
in the amount of cocksfoot is particularly significant as it is the grasses which provide the winter production in these environments. It is clear from these results that cocksfoot should be included in the initial seed mixture, although it may be a number of years before the grass becomes a significant component of the sward. Cullen (1966) and Douglas (1966) showed that grass establishment is poor where there is competition from the existing sward, hence the cocksfoot should be included in the initial oversowing mixture and not applied when a maintenance dressing of fertilizer is applied.

It has been shown that, in the improvement of a tussock country property, it is very necessary to provide supplementary winter feeding in the form of lucerne hay. The lucerne stands are grown on the dry terrace and fan soils in the valley floors. Work at Tara Hills Research Station by Douglas and Ludecke has shown that the pure lucerne stands yield substantially more than lucerne-grass mixtures sown in alternate rows. Lucerne and cocksfoot was the best lucerne-grass mixture in this trial. In another trial it was shown that the production was superior in lucerne-cocksfoot mixtures in comparison with lucerne and cocksfoot sown in alternate rows: the production of lucerne-cocksfoot mixtures in this trial was slightly inferior to lucerne alone.

\section{Utilization}

To obtain successful establishment of oversown species and efficient utilization, it is essential to have the improved blocks of such a size that the swards can be managed correctly. The size of the improved blocks on a particular property will depend on the flock size. The country should be aerially improved in July and August and under Central Otago conditions it is very necessary to spell the oversown block in the first year from September until late January, in order to obtain good establishment of oversown species.

In the areas of fescue tussock country in Central and North Otago where the rainfall is 20 to 25 in., there are generally tremendous differences in cover between country of sunny and dark aspects. The. soils on the sunny slopes are steepland soils associated with the brown-grey earths, and on the dark slopes steepland soils associated with dry sub-hygrous yellow-grey earths. The dark country can 
be improved markedly by aerial topdressing and oversowing but grazing observational studies by Kinder at Tara Hills showed that the sheep still grazed the sunny faces and allowed the dark faces to become rank. Hercus (1961) showed that if the sunny depleted country which is too dry to oversow can be spelled during the seeding period of the native grasses then quite spectacular improvement can be effected. On some properties where there are large, unbroken areas of both dry, depleted sunny country and dark country, it is possible to fence the dark from the sunny. In the hogget block of 1,400 acres at Tara Hills Research Station, two faces are predominantly sunny and the other two are predominantly dark. In one half of the block, the sunny and dark country were fenced off separately in 1963 and in the other half the sunny and dark are not separated. The changes in botanical composition on the different aspects with the different grazing systems are being studied by Molloy. In the controlled grazing blocks, in contrast to the uncontrolled, there has been far better utilization of fodder on dark aspects, and on both sunny and dark aspects there has been a decrease in the amount of bare ground and an increase in cover of native and introduced grasses, clovers and other herbs.

In trials at Tara Hills in each year from 1962 to 1964, conducted by Lewis, Scales and Ludecke, it was shown conclusively that merino lambs weaned at 12 weeks of age did as well as or slightly better than lambs weaned at 16 weeks of age. It was also shown that the liveweight gain of the weaned lambs was the same on irrigated pastures as on improved tussock country. The findings of Scales (1966) at Tara Hills, that level of milk production by merino ewes has reached a low level by the twelfth week of lactation, gives further support to the practice of early weaning. Early weaning of merino lambs has a number of advantages. The ewes and lambs can be taken off the improved winter country where they have lambed earlier, and before the pastures are adversely affected by drought conditions in January. The hoggets can be given preferential treatment so that good growth rates are obtained. This is important in that Coop (1962) has shown that high body-weights in ewes at the two-tooth stage are essential for satisfactory lambing percentages. 
In these trials, responses to drenching with thiabendazole were obtained in the lambs weaned on to irrigated pasture. There was a response to dosing with selenium in the presence of thiabendazole. Trials on farmers' properties have also shown that good responses are obtained to anthelmintic drenches when fine wool sheep are grazed on improved tussock blocks.

In Central Otago on improved properties it is necessary to dose merino ewes and lambs with selenium to guard against congenital white muscle disease and barrenness in ewes.

A number of liveweight and fleeceweight observations in the Wanaka district of Central Otago have shown that hoggets can be wintered on autumn-spelled, aeriallyimproved tussock country. The stocking rate over the winter months on these improved swards is 1 to $1 \frac{1 / 2}{2}$ hoggets per acre.

If the hoggets on a high country property are fed on the improved tussock country, it will be necessary to supply at least some of the ewe flock with supplementary feed. Trials have been conducted at Tara Hills for the last five years on supplementary feeding merino ewes by Lewis, Scales and Ludecke. In these trials, conducted over a 100-day period during the winter, it has been shown that merino ewes can be wintered satisfactorily on $1 \% \mathrm{lb}$ lucerne hay per head per day with no other intake. By feeding this ration of hay there was no effect on wool production or lamb growth rates, and ewe body-weights were maintained. The indications from these trials are that weekly feeding is nearly as good as daily feeding and there was little advantage in varying the level of feeding to give a rising plane of nutrition in late pregnancy. In 1964 it was shown that merino ewes can be wintered satisfactorily on $1 \mathrm{lb}$ of oats per head per day. Assuming a winter of 100 days, a merino ewe requires $150 \mathrm{lb}$ hay or $2 \frac{1 / 2}{}$ bales. This is considered to be valuable information to farmers who are developing their properties as it gives some indication of the area of lucerne required. In the Wanaka district of Central Otago good dry land lucerne stands yield 100 bales per acre. On properties where paddocks are being developed, brassica crops can provide good supplementary feed for fine wool sheep.

It is often considered that when a tussock country property is improved, it is necessary to alter the breed of 
TABLE 5: INTERIM RESULTS OF TRIAL COMPARING CORRIEDALE AND MERINO BREEDS, TARA HILLS RESEARCH STATION

\begin{tabular}{|c|c|c|c|}
\hline & $\begin{array}{l}\text { Body-weight } \\
\text { (lb) }\end{array}$ & $\begin{array}{l}\text { Greasy } \\
\text { Wool Weight } \\
\text { (lb) }\end{array}$ & Lambing $\%$ \\
\hline \multicolumn{4}{|c|}{$\begin{array}{c}\text { Ewes (Shearing } 1966 \\
\text { Lambing 1965) }\end{array}$} \\
\hline Corriedale 2-th & 106.4 & 9.1 & 一 \\
\hline Merino 2-th & 93.3 & 9.5 & - \\
\hline Corriedale 4-th & .... 119.0 & 9.7 & 94.0 \\
\hline Merino 4-th & . 104.3 & 10.4 & 92.4 \\
\hline \multicolumn{4}{|c|}{ Wethers (Shearing 1965) } \\
\hline Corriedale 2-th & $\ldots \quad 103.3$ & 10.8 & \\
\hline Merino 2-th & 91.1 & 12.4 & \\
\hline
\end{tabular}

sheep. At Tara Hills, which is a highly improved property, a trial comparing corriedales with merinos is being undertaken. In this experiment the progeny from each breed born on Tara Hills are being compared and all sheep are-given identical treatment. Interim results from this trial are shown in Table 5. All sheep at Tara Hills are blade shorn.

The merinos have lower body-weights but greasy wool production is superior. Lambing percentage in two-tooths last year was the same. So far, these production figures indicate there is no justification in changing the brekd with improvement work. It is stressed that these are only interim results and before any definite conclusions are drawn it will be necessary to have lifetime production data. It must be realized that with merinos the carrying capacity will be higher than with corriedales. It is realized, however, that it may be necessary to alter the breed for other reasons, such as footrot, or if the difference in sale value of surplus stock was sufficiently great.

\section{Production}

With the exception of the work by O'Connor (1960, 1966) and Ludecke (1960, 1962), very little work has been undertaken in measuring the increases in pasture production brought about by improving low altitude tussock country. This lack of information is due to the difficulties encountered in making measurements. There have been numerous references to the increases in pastoral production attained by successful farmers. 
TABLE 6: AVERAGE FLEECEWEIGHTS OF HOGGETS GRAZED ON UNIMPROVED AND IMPROVED TUSSOCK

\begin{tabular}{|c|c|c|}
\hline & $\begin{array}{c}\text { Grazed on Unimproved } \\
\text { Tussock, January till } \\
\text { mid-July } \\
\text { (lb) }\end{array}$ & $\begin{array}{l}\text { Grazed Entirely on Im- } \\
\text { proved Tussock } \\
\text { (lb) }\end{array}$ \\
\hline $\begin{array}{l}\text { Wethers } \\
\text { Ewes } \\
\text { Average }\end{array}$ & $\begin{aligned} & 3.9 \\
& 4.2 \\
& 4.1 \\
\text { (Range } & 2.9 \text { to } 4.9 \text { ) }\end{aligned}$ & $\begin{aligned} & 6.6 \\
& 6.6 \\
& 6.6 \\
& \text { (Range } 4.9 \text { to } 8.2 \text { ) }\end{aligned}$ \\
\hline
\end{tabular}

Very little detailed work has been undertaken in measuring the actual increases in stock production resulting from oversowing and topdressing. Some work has been undertaken by Ludecke on the property of J. R. Scurr, Cardrona, Wanaka. On this property in the 1963-4 season all the.ewes lambed on improved tussock country blocks. Of the 950 hoggets kept on this property in the winter of 1964, 730 were grazed on unimproved tussock country from January until mid-July and improved country from July until shearing in late September. The remaining 220 hoggets were grazed. on improved country for the complete year; from April until shearing they were grazed on the 300-acre block already described in this paper. The sheep on this high country property are all blade shorn. The average unskirted fleeceweights of 50 hoggets selected at random from each group are shown in Table 6.

In this season there was a $62 \%$ increase in wool production brought about by feeding hoggets on a better plane of nutrition. It is considered that the wool weight of hoggets on this property before improvement work was undertaken was $4.5 \mathrm{Ib}$ per head. In the 1965- 6 season, the average fleeceweight of 50 hoggets selected at random was $7.0 \mathrm{lb}$. In the 1963-4 season, the death rate from weaning until shearing was $5 \%$ for the hoggets grazing on unimproved country, and less than $1 \%$ for hoggets grazing on improved country. A simple economic analysis showed that the cost of the improvement work on this Wanaka property was more than compensated for by increased returns from hoggets alone. The wool weight in the ewe and wether flocks has also increased markedly and the lambing percentage has been raised by 15 to $20 \%$. 
The old ewes are retained for another year and are mated to fat lamb sires, and a high percentage of lambs are sold fat off the mothers.

\section{Conclusion}

While a great deal of research work has been undertaken into the improvement of low altitude tussock country, there are still many problems. In particular it is considered that research should be undertaken into the following aspects :

(1) Establishment of maintenance fertilizer requirements. Work using the technique described by Ludecke (1966) has been commenced in the Arrowtown district.

(2) The control of insect pests, particularly grass-grub and porina.

(3) The introduction and production of other grasses besides cocksfoot.

(4) Further data on efficient techniques of utilizing improved pastures.

(5) Production and carrying capacities of impoved swards.

The development of low altitude tussock country in Otago is the cheapest land development in N ew Zealand: The initial cost of seed and fertilizer applied to fescue tussock country in the Wanaka district is $£ 35 \mathrm{~s}$. per acre. A maintenance dressing of fertilizer should be made every two to three years. In Central Otago the surface is barely scratched yet and the future looks to be extremely bright. McPherson (1963) estimated that in Central and North Otago there were $1,035,000$ acres of hill country which could be developed in the manner described in this paper. None of this improvement work, however, is possible without the control of the rabbit.

\section{REFERENCES}

Cullen, N. A., 1966: Proc. Internat. Grassl. Cong., Helsinki (in press).

Cullen, N. A.; Ludecke, T. E., 1966: Proc. 28th Conf. N.Z. Grad Ass. 96-104.

Coop, I. E., 1962: N.Z. l. agric. Res.., 5: 249-64.

Douglas, J. A., 1966: N.Z. agric. Sci., 1: 18.

Hercus, J. M., 1961: N.Z. I. Agric., 103:257-61.

Lobb, W. R.; Bennetts, R. L., 1958: N.Z. J. Agric., 96:537-49. 
Leamy, M. L., 1966: Proc. 28th Conf. N.Z. Grassl. Ass., 7-18.

Ludecke, T. E., 1960: Proc. 22nd Conf. N.Z. Grassl. Ass., 96110

-- 1962a: Proc. 24th Conf. N.Z. Grassl. Ass.:29-41:

1962b: M. Agr. Sc. thesis, Lincoln College.

1965: Proc. 27th Conf. N.Z. G rassl. Ass.: 129-38.

-- 1966a: N.Z. agr. Sci., I(4) : 7-10.

1966b: Proc. Internat. Grassl. Congr., Helsinki (in press).

McLcod, C. C., 1961: N.Z. I. Agric., 102: 225-36.

McPherson, G. K., 1963: Proc. N.Z. Inst. agric. Sci., 9:157-63.

Molloy, B. P. J.. 1964: N.Z. J. Agric., 109: 105-18.

1966: Ph.D. thesis, Lincoln College.

O’Connor, K. F., 1960: Proc. 10th Lincoln Coll. Farmers Conf.: 82-94.

1966: Proc. 16th Lincoln Coll. Farmers Conf.:77-87.

Scales, G. H., 1966: M. Agr. \$. thesis, Lincoln College.

Walker, T. W.; Adams, A. F. R.; Orchistron, H. D., 1955: N.Z. J. Sci.

Tech., $A 36:$ 470-82.

\section{DISCUSSION}

Is there any response to preconditioning of the site before oversowing, i.e., by burning or grazing?

In the oversowing of fescue tussock country in Central Otago, it has been found very important to retain the tussock cover. Results following burning or very hard grazing are often very poor, particularly if any hot conditions prevail after oversowing.

\section{How high up the mountains of Central Otago is it economical to topdress?}

This depends to a large extent on the aspect. On sunny country, it is economical to an altitude of approximately 3,000 to $3,500 \mathrm{ft}$, whereas, on dark country, where the soils are more leached, it is economical only to an altitude of 2,500 to $3,000 \mathrm{ft}$.

Were the corriedales in the breeds-of-sheep trial born and bred at Tara Hills?

Yes. Both the corriedales and merinos in this trial are given identical treatment and both flocks were born and bred on Tara Hills. 